\title{
Development of an Ethnomathematics-Based e-Module to Improve Students' Metacognitive Ability in 3D Geometry Topic
}

\author{
https://doi.org/10.3991/ijim.v16i03.24949
}

\author{
Sutarto $^{1(凶)}$, Ahmad Muzaki $^{1}$, Intan Dwi Hastuti ${ }^{2}$, Sukron Fujiaturrahman ${ }^{2}$, \\ Zainuddin $\mathrm{Untu}^{3}$ \\ ${ }^{1}$ Faculty of Sciences Technology and Applications, Universitas Pendidikan Mandalika, \\ Mataram, Indonesia
}

${ }^{2}$ Faculty of Teacher Training and Education, Universitas Muhammadiyah Mataram, Mataram, Indonesia

${ }^{3}$ Faculty of Teacher Training and Education, Universitas Mulawarman, Samarinda, Indonesia sutarto@undikma.ac.id

\begin{abstract}
Since the Covid 19 Pandemic by the end of 2020, the learning process has shifted from school to online home-based- learning. Several technologies are applied for enabling students' participation. Technology-based learning needs to be designed to be attractive and integrated with local culture. The present study developed a valid, practical, and effective Sasak ethnomathematics-based e-Module. The e-Module was mainly designed to improve students' metacognitive abilities. The study used development research using a 4D development model consisting of four categories: defining, designing, developing, and disseminating. The research was conducted in one of the elementary schools in West Lombok. Ten students of grade five and 30 students of grade six were selected for large-scale trials. The validity test showed that the ethnomathematics-basede-Module was highly feasible to be used as a learning resource with an average score of 3.65. The questionnaire's analysis of students' responses showed that the e-Module fell into the practical category with a practicality percentage of $89 \%$. The results of data analysis using independent sample T-Test showed that the T-test value was $0.00<0.05$, thus the results of the study revealed a significant difference. Overall, the ethnomathematics-based- e-Module was valid, practical, and effective for improving students' metacognitive abilities on spatial material. The students can access the e-Module via smartphones or laptops, allowing them to remotely without time restrictions.
\end{abstract}

Keywords—e-Module, ethnomathematics, problem-solving, building space

\section{$1 \quad$ Introduction}

Since Covid 19 Pandemic hit the world by the end of 2020, the learning process has shifted from school to online home-based- learning. Several technologies are applied for enabling students' participation. Technology-based learning needs to be attractive 
to maintain students' enthusiasm and focus on independent learning. Technology-based learning facilitates the use of electronic modules (e-Module). The e-Module is one of the teaching materials that present separate learning materials arranged systematically in electronic format to achieve particular learning objectives. It is designed in animation and audio to make it more exciting and interactive [1]. The e-Module is an efficient, effective, and interactive alternative learning source that can be accessed anytime and anywhere via a smartphone or laptop with several supporting devices [2].

Observations and interviews conducted at three elementary schools in West Lombok, Indonesia, showed that mathematics classes were insufficient innovation and did not involve using technology. Learning was conducted teacher-centered, with most students' activities focused on textbooks and was not linked to local wisdom. In addition, students' success was fully emphasized on the cognitive aspect. The questionnaire spread in three elementary schools showed that $60 \%$ of students had difficulty understanding mathematics textbooks.

Mathematics learning needs to be linked with the local culture [3], [4]. This can be done through ethnomathematics. Elements of Sasak culture can be used for exciting and fun mathematics learning at the primary level [5]. Ethnomathematics of the Sasak tribe is extracted from traditional houses, special foods, and handicrafts. Ethnomathematics-based teaching materials in geometry topics need to be designed to provide opportunities for elementary school students to build knowledge and develop their potential according to the region's characteristics. Students can achieve learning goals by referring to the cultural values of their area to build good character among the society.

Mathematical concepts associated with culture and everyday experiences will improve students' ability to make meaningful connections and deepen their understanding of mathematics [6]. Applying ethnomathematics in mathematics will motivate students, create more meaningful learning, and enable students to realize that mathematics is helpful in real life [4], [6]. Another finding showed that using a local culture-based model combined with a scientific approach can foster higher-order thinking skills [7].

The scientific approach is nature-oriented learning [8]. Activities in the scientific method include: 1) observing, 2) trying, 3) reasoning, 4) asking questions, and 5) communicating [8], [9]. In implementing the 2013 curriculum in Indonesia, the scientific approach is one of the most recommended approaches as it can develop students' metacognitive competence, especially towards science and technology [10].

Metacognition ability is part of the 21 st-century skills that need to be trained by students and is the key to the success of 21-century education [11], [12]. Metacognition is a higher-order thinking ability that involves understanding, analyzing, and developing cognitive processes [13], [14]. There are three metacognitive ability indicators, including planning, evaluation, and monitoring [15].

No previous research has developed an ethnomathematics-based e-Module that specifically addresses the culture of the Sasak tribe on geometry topic and analyzes the effectiveness of an ethnomathematical-based e-Module in terms of metacognitive abilities. Patri \& Heswari developed an e-Module integrated with Jambi culture to improve logical thinking skills [7]. Serevina, Sunaryo, Raihanati, Astra, \& Sari set an e-Module based on Problem Based learning on heat and temperature materials 
to improve science skills [16]. Kurniasari, rakh-mawati, \& Fakhri have developed an e-Module characterized by the ethnomathematics of Lampung culture in twodimensional figure material [17]. It is necessary to create an ethnomathematics-based e-Module, especially for the Sasak tribe- for primary students and to determine its effectiveness through indicators of metacognitive ability.

\section{$2 \quad$ Literature review}

\subsection{Electronic module (e-Module)}

The e-Module is independent systematically arranged electronic learning materials that enable students to achieve specific learning objectives [2]. The use of e-Modules is following the principles of 21st-century learning of technology use for learning. An e-Module is more practical than the printed version since it is accessible by smartphone and functional [2]; thus, it can be accessed anytime and anywhere via smartphones or laptops with the supporting software. Mobile devices such as a smartphone are suitable for children's lifestyles because there is no need to sit or school to use the device. They only need students to activate smartphones [18]. Children nowadays use this technology earlier [19]. The e-Module is presented in an electronic format that includes animation, audio, and navigation, allowing interaction between users and the program.

Several studies have revealed that digital media can help children understand abstract concepts early [20]. The involvement of digital media in the school environment can develop logical thinking and strengthen students' problem-solving skills [21].

\subsection{Digital mathematics activities and children}

Research on the use of digital technology in mathematics learning is not new [22]. Digital technology becomes part of mathematics learning to increase engagement and understanding in the learning process; mobile technology can make mathematics more meaningful [23] because it allows children to learn and practice skills interestingly and interactively [24]. Digital activities effectively promote mathematics, natural sciences, and languages, where specific goals can be selectively defined and developed in contexts related to specific learning activities and targets [25]. Studies have shown the benefits of using digital at the elementary school level as follow:

a. Digital activities can provide various educational services to children. Several studies have suggested that well-designed educational activities can motivate and encourage learning more than traditional teaching methods [26].

b. By using digital activities, students can learn cognitive abilities through repetition [27].

c. In primary education, students often engage in collaboration while playing digital activities [28].

The use of technologies could effectively support the learning process, particularly in mathematics [29]. Integrating mobile devices into the primary school curriculum increases elementary school students' interest [30]. The use of technology provides a 
positive role in improving students' early math skills. The use of mobile technology in mathematics education can encourage meaningful student engagement [29].

\subsection{Ethnomathematics through mobile devices}

Ethnomathematics represents local cultural objects in mathematical concepts. The concept of local culture in mathematics learning can improve students' knowledge and reasoning [31]. Ethnomathematics-based understanding affects problem-solving abilities by connecting real-world situations and cultural values that grow in society [3]. To facilitates a meaningful understanding of mathematics, it is necessary to integrate culture in learning mathematics. Integration of mathematics and local culture is an effective means to grow character and noble values in society. The elements of Sasak culture integrated with 3D Shape materials include traditional Sasak's houses, special foods, and traditional handicrafts.

The e-Module must have the following characteristics: a) Easy to use so that children can easily use it, b) Provide pictures related to the traditional culture of the Sasak Tribe, c) Combine animation and sound.

\subsection{Metacognitive ability}

Metacognitive abilities can encourage higher-order thinking skills [32]-[34]. Metacognitive skills help students in solving problems. Metacognitive abilities develop continuously with age development. Early engagement with metacognitive activities can lead to good metacognitive skills [10]. Metacognitive knowledge is one of the essential goals in the curriculum of Indonesia. Anderson \& Krathwohl explained three indicators of metacognitive ability, i.e., planning, evaluation, and monitoring [15]. Planning consists of setting goals, linking with prior knowledge, and choosing the appropriate strategy. The assessment consists of realizing one's level of understanding and how to select the proper method. Monitoring checks one's progress and determines the right approach when the initial strategy does not work.

\section{$3 \quad$ Method}

\subsection{Research setting}

This research was conducted from March 2021-May 2021 in one of the elementary schools in West Lombok, grade VI primary school in 2020/2021. The total number of subjects in this study was 30 students.

\subsection{Research design}

This study used the 4D model. This model consists of 4 stages, they are 1) defining, 2) designing, 3) developing, and 4) disseminating. The defining stage in this research consists of five activities: preliminary analysis, student analysis, concept analysis, task 
analysis, and formulation of learning objectives. In the initial analysis activity, the researcher analyzed the curriculum related to the Competencies and Basic Competencies of the material to be developed. Student analysis activities aim to determine students' characteristics, level of student cognitive development, and student motivation. Student analysis was carried out by observation during the learning process in the classroom and interviews with teachers and students. Concept analysis activities were carried out to find the content of the material in the module to be developed through activities of detailing, identifying, and systematically compiling the material, the concepts of relevant building blocks volume taught based on the initial analysis. Task analysis aims to identify tasks or practice questions, and the primary skills students do during learning which the researcher then analyzes into a more specific sub-skills framework.

Furthermore, at the designing stage, the researcher prepared the e-Module design into steps; 1) test preparation, 2) media selection, and 3) format selection. Test preparation is an initial stage to measure the level of students' initial metacognitive skills. Media is selected to ensure that it fits the material to be taught and the characteristics of students. In the present research, the media is ethnomathematics based- e-Module. After the three stages were carried out, a draft or design of the ethnomathematics-based- e-Module was created following the content framework of the curriculum and material analysis.

At the development stage, the activities carried out were expert validation and test development. Expert validation aims to validate or assess the feasibility of the developed e-Module to a team of experts in their field. The instrument used to validate is a feasibility assessment questionnaire that includes content, presentation, grammar, and design components. After obtaining an assessment from the validator, suggestions for improvements to the e-Module were obtained and became the critical basis for revision. The evaluation aimed to make the e-Module developed to meet the concept, tested, and valuable. The four aspects in validation included content validation, presentation validation, language validation, and validation of the design components of e-Module. The validators stated that the e-Module was valid can be tested on research subjects.

In the test development stage, the researcher tested the draft on the actual subject. The e-Modules were tested in small classes before trying in large classes. The test results were used to improve the product to gain effective outcomes. The effectiveness of the module was evidenced by the independent sample T-Test used to analyze the research data. While the trial was conducted in a small class, the researchers observed, obtaining responses from questionnaires and interview comments. The instrument used in the small-scale practice was non-test instruments of observation sheets, validation sheets, and student questionnaires. After receiving input from a small-scale trial and revision, the e-Module was tested on a large-scale group to achieve the developed module's objectives and effectiveness. At this stage, the achievement of goals was measured to obtain thee-Modules' effect on students' metacognitive abilities. The instrument used was a problem-solving test instrument.

The dissemination stage was the socialization stage of learning media and e-Module links. They were distributed through Whatsapp Group. The dissemination stage aims to disseminate the e-Module. The developed e-Module was prepared using a scientific approach, including observing, asking, trying, and reasoning activities. 


\subsection{Data analysis technique}

A quasi-experimental design with a pretest and post-test control group design was the research design used for data analysis. It was used to find the results of the pretest and post-test of the e-Module use for developing students' metacognitive abilities. The data collection techniques included expert validation tests, documentation studies, observations, and student learning outcomes. A questionnaire instrument was used for expert validation to gain a valid e-Module based on the expert overview. Comment as used to collect data related to the activities during learning activities with e-Modules. A problem-solving test was used to obtain data about the e-Module on students' metacognitive abilities. The effect of using the e-Module on metacognitive knowledge was measured by analyzing the students' scores. The instrument used to assess metacognitive ability was pretest and post-test questions consisting of one descriptive question. The effect of using the e-Module on metacognitive knowledge was gained through a paired sample T-Test with SPSS 17.00 for windows. For paired sample T-test, the data used must be normally distributed to analyze the data obtained. This value then determines the decisions taken in the study. Table 1 shows indicators used in determining the level of metacognitive [15].

Table 1. Indicators and description of metacognitive ability

\begin{tabular}{|l|l|l|}
\hline \multicolumn{1}{|c|}{ No } & \multicolumn{1}{|c|}{ Indicator } & \multicolumn{1}{c|}{ Description } \\
\hline 1 & Plan & $\begin{array}{l}\text { Setting goals (P1) } \\
\text { Enabling relevant resources (P2) } \\
\text { Choosing the right strategy (P3) }\end{array}$ \\
\hline 2 & Evaluation & $\begin{array}{l}\text { Determine the level of understanding of a person (E1) } \\
\text { How to choose the right strategy (E2) }\end{array}$ \\
\hline 3 & Monitoring & $\begin{array}{l}\text { Checking one's progress (M1) } \\
\text { Choose the appropriate improvement strategies when } \\
\text { the chosen strategy does not work. (M2) }\end{array}$ \\
\hline
\end{tabular}

\section{$4 \quad$ Result and discussion}

\subsection{Defining stage}

At the defining stage, the researchers analyzed the applied curriculum, i.e., the 2013 curriculum. The analysis found the Core Competencies and Basic Competencies to be developed to determine the volume of geometric shapes (prisms, cylinders, pyramids, cones, spheres, and a combination of several forms) and solve problems related to the importance of the figures. From observations at the initial analysis stage, the researchers found that students' problem-solving abilities were lacking. Students were only involved in routine questions with assessment emphasizing cognitive aspects. 


\subsection{Designing stage}

The researcher drafted e-Module through several stages at the design stage, i.e., 1) test preparation, 2) media selection, and 3) format selection. The preparation of the test was in the form of 5 problem-solving questions. The e-Module was selected as a media based on ethnomathematics by taking elements of Sasak culture, which includes traditional houses, special foods, and handicrafts. The draft or product design- the e-Module of ethnomathematics - was produced after the three stages were carried out. In the format selection activity, the researcher designed the material's content integrated with Sasak culture and combined a scientific approach. The purpose of incorporating elements of Sasak culture in the material is to motivate students to continue learning mathematics, create more meaningful learning, and enable students to know the direct benefits of learning mathematics in real life.

\subsection{Developing stage}

The development phase consists of two activities, i.e., validation and testing of the e-Module. At this stage, a revised draft of the module was developed based on input from experts and data obtained through small-scale trials. Activities at this stage included expert validation and some limited tests. Expert validation was carried out by two mathematics education lecturers and two sixth-grade teachers (see Table 2). The practicality and effectiveness of the e-Module were also determined from the results of the testing activities. Responses from students (users) of the e-Module on the questionnaire and interviews show that the e-Module was user-friendly and the media meets the effective criteria based on the metacognitive ability test.

e-Module validity.

Table 2. e-Module validity

\begin{tabular}{|l|l|c|l|l|}
\hline \multicolumn{1}{|c|}{ No } & \multicolumn{1}{|c|}{ Validator } & Score & \multicolumn{1}{|c|}{ Validation Criteria } & \multicolumn{1}{c|}{ Information } \\
\hline 1 & X-1 & 3.53 & Very Valid & $\begin{array}{l}\text { Enlarge the image size in } \\
\text { practice questions }\end{array}$ \\
\hline 2 & X-2 & 3.57 & Very Valid & No revision \\
\hline 3 & X3 & 3.67 & Very Valid & No revision \\
\hline 4 & X-4 & 3.75 & Very Valid & No revision \\
\hline & Average & 3.63 & Very Valid & \\
\hline
\end{tabular}

Table 2 shows that the average value of e-Modul validation was 3.63 (high validity) criteria indicating that the e-Module was feasible to use without significant revisions.

e-Module practicality. Based on the results of interviews and questionnaires, the e-Module was practical $(89,67 \%)$. Table 3 shows the indicators and responses to the e-Module usage questionnaire. 
Table 3. Indicators of the e-Module usage questionnaire

\begin{tabular}{|c|c|c|c|c|c|}
\hline \multirow{2}{*}{ No } & \multirow{2}{*}{ Indicators } & \multicolumn{4}{|c|}{$\begin{array}{c}\text { Percentage of Student Responses in Each } \\
\text { Category }(\%)\end{array}$} \\
\hline & & $\begin{array}{l}\text { Strongly } \\
\text { Disagree }\end{array}$ & Disagree & Agree & $\begin{array}{c}\text { Strongly } \\
\text { Agree }\end{array}$ \\
\hline \multicolumn{6}{|c|}{ Content Aspect } \\
\hline 1. & $\begin{array}{l}\text { The material presented is following the learning } \\
\text { objectives }\end{array}$ & 76.67 & 16.67 & 3.33 & 3.33 \\
\hline 2. & $\begin{array}{l}\text { The learning steps in the e-Module are easy to } \\
\text { follow }\end{array}$ & 70.00 & 20.00 & 6.67 & 3.33 \\
\hline 3. & $\begin{array}{l}\text { The activities in the module are fun because they } \\
\text { relate to the life around students. }\end{array}$ & 73.33 & 16.67 & 3.33 & 6.67 \\
\hline \multicolumn{6}{|c|}{ Language Aspect } \\
\hline 4. & The e-Module can be read clearly & 73.33 & 20.00 & 3.33 & 3.33 \\
\hline 5. & The material presented is in easy-to-understand & 60.00 & 26.67 & 10.00 & 3.33 \\
\hline 6. & The language used is communicative & 56.67 & 33.33 & 6.67 & 3.33 \\
\hline 7. & $\begin{array}{l}\text { Instructions for use, learning objectives, and } \\
\text { learning activities in the e-Module are pretty clear }\end{array}$ & 60.00 & 30.00 & 3.33 & 6.67 \\
\hline \multicolumn{6}{|c|}{ Benefit Aspect } \\
\hline 8. & Easy-to-use & 66.67 & 23.33 & 6.67 & 3.33 \\
\hline 9. & It triggers me to study harder & 56.67 & 33.33 & 6.67 & 3.33 \\
\hline 10. & $\begin{array}{l}\text { The availability of pictures in the module makes it } \\
\text { easier for me to do practical activities }\end{array}$ & 60.00 & 23.33 & 10.00 & 6.67 \\
\hline
\end{tabular}

Table 2 shows that the students positively responded to e-Module based on ethnomathematics for each indicator. They could easily follow each activity on the module and understand the material. The competency test at the end of the module was able to measure students' mathematical problem-solving abilities. The designed activities were always related to the culture closely associated with the students' daily lives and equipped with pictures of objects they often encounter. Below are excerpts from the interviews of researchers, students, and teachers.

Researcher interviews with students

R: $\quad$ Do you understand the material easily after doing the learning activities associated with Sasak culture?

S1: $\quad$ Yes, it is easier for me to understand. I often find examples and pictures shown on e-Modules.

R: $\quad$ What is your first impression when the teacher linked the learning activities with Sasak culture?

S1: It's fun because, honestly, I've never studied mathematics associated with traditional Sasak houses, food, and handicrafts before. It is different from the textbooks that we've learned so far.

R: What is your first impression when working on/using the e-Module?

S1: Ifelt more motivated to follow the activities; the pictures are good. The design is also good. It is also easier for me to understand this material after working on the E-Modul. 
Interviews with researchers and teachers

R: In your opinion, can this e-Module help students understand spatial structure?

T1: Yes, because the integration of the E-Modul with Sasak culture makes learning more meaningful for children, it turns out that mathematics is close to their daily lives.

Interviews with both learners and teachers show that e-Module could motivate students to learn mathematics based on ethnomathematics.

e-Module effectiveness. From the results of data analysis (interviews and student work), the percentage graphic of indicators metacognitive ability in Figure 1 as follows.

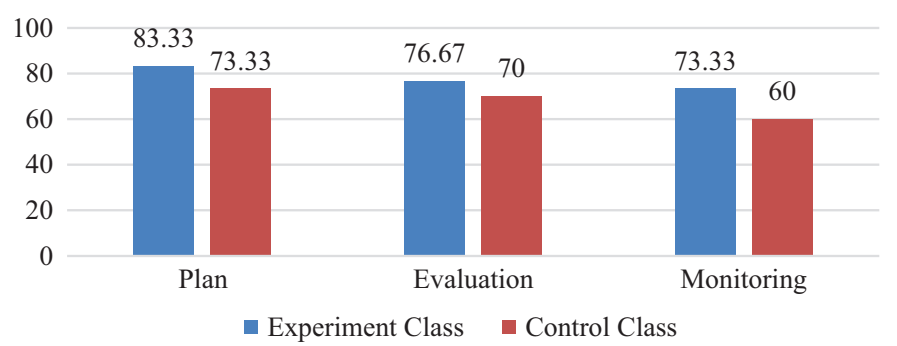

Fig. 1. Percentage of indicators of metacognitive ability

The effectiveness of the e-Module was tested by using an independent sample T-Test. The experimental class was applied with an ethnomathematics-based-e-Module, while an ordinary printed module was used for the control class. The normality test of the data was checked before further analysis. The number of samples in this study was 60 students. As shown in Table 4 and Table 5, the pretest results from both the experimental class and control class indicated the similarity or not significant difference.

Table 4. The results of pretest data analysis

\begin{tabular}{|l|c|c|c|c|}
\hline \multicolumn{1}{|c|}{ Group } & N & Mean & Std. Deviation & Std. Error Mean \\
\hline Experiment Class & 30 & 1.5667 & .77385 & .14129 \\
\hline Control Class & 30 & 1.5333 & .68145 & .12441 \\
\hline
\end{tabular}

Based on Table 4, the average value of the experimental class students was 1.5667 with a standard deviation of 0.77835 , while the average value of the control class students was 1.5333 with a standard deviation of 0.68145 . Table 5 shows that the data obtained from the pretest value between the two groups was $[\mathrm{t}(30)=0.367, \mathrm{p}>0.05]$, meaning that it was not significantly different. The results of data analysis using independent sample T-Test showed that students in the experimental and control classes had similar abilities before treatment. 
Table 5. The comparison of pretest score using independent sample T-Test

\begin{tabular}{|c|c|c|c|c|c|c|c|c|c|c|}
\hline & & \multicolumn{2}{|c|}{$\begin{array}{l}\text { Levene's } \\
\text { Test for } \\
\text { Equality of } \\
\text { Variances }\end{array}$} & \multicolumn{7}{|c|}{ t-test for Equality of Means } \\
\hline & & \multirow[t]{2}{*}{$\mathbf{F}$} & \multirow[t]{2}{*}{ Sig. } & \multirow[t]{2}{*}{$\mathbf{t}$} & \multirow[t]{2}{*}{ Df } & \multirow[t]{2}{*}{$\begin{array}{c}\text { Sig. } \\
\text { (2-tailed) }\end{array}$} & \multirow[t]{2}{*}{$\begin{array}{c}\text { Mean } \\
\text { Difference }\end{array}$} & \multirow[t]{2}{*}{$\begin{array}{l}\text { Std. Error } \\
\text { Difference }\end{array}$} & \multicolumn{2}{|c|}{$\begin{array}{c}95 \% \\
\text { Confdence } \\
\text { Interval of the } \\
\text { Difference }\end{array}$} \\
\hline & & & & & & & & & Lower & Upper \\
\hline \multirow[t]{2}{*}{ Pre-test } & $\begin{array}{l}\text { Equal } \\
\text { variances } \\
\text { assumed }\end{array}$ & .828 & .367 & .177 & 58 & .860 & .03333 & .18826 & .34350 & .41017 \\
\hline & $\begin{array}{l}\text { Equal } \\
\text { variances } \\
\text { not assumed }\end{array}$ & & & .177 & 57.087 & .860 & .03333 & .18826 & .34363 & .41030 \\
\hline
\end{tabular}

Table 6. The results of post-test data analysis

\begin{tabular}{|l|c|c|c|c|}
\hline \multicolumn{1}{|c|}{ Group } & N & Mean & Std. Deviation & Std. Error Mean \\
\hline Experiment Class & 30 & 4.3667 & 1.37674 & .25136 \\
\hline Control Class & 30 & 2.7667 & 1.07265 & .19584 \\
\hline
\end{tabular}

Based on Table 6, the average value of the experimental class students is 4.367 with a standard deviation of 1.37674 , while the average value of the control class students is 2.7667 with a standard deviation of 1.07265 . Table 7 shows that the data obtained that the post-test value between the two groups was $0.00(\mathrm{p}=<0.05)$, meaning that it is significantly different. The results of data analysis using the independent sample T-Test showed that students in the experimental and control classes had different abilities after treatment. From the results of data analysis, there was a significant effect after treatment using e-Module.

Table 7. The comparison of the post-test score using independent sample T-Test

\begin{tabular}{|c|c|c|c|c|c|c|c|c|c|c|}
\hline & & \multicolumn{2}{|c|}{$\begin{array}{c}\text { Levene's } \\
\text { Test for } \\
\text { Equality of } \\
\text { Variances }\end{array}$} & \multicolumn{7}{|c|}{ t-test for Equality of Means } \\
\hline & & \multirow[t]{2}{*}{$\mathbf{F}$} & \multirow[t]{2}{*}{ Sig. } & \multirow[t]{2}{*}{$\mathbf{t}$} & \multirow[t]{2}{*}{ Df } & \multirow[t]{2}{*}{$\begin{array}{c}\text { Sig. } \\
\text { (2-tailed) }\end{array}$} & \multirow[t]{2}{*}{$\begin{array}{c}\text { Mean } \\
\text { Difference }\end{array}$} & \multirow{2}{*}{$\begin{array}{c}\text { Std. } \\
\text { Error } \\
\text { Difference }\end{array}$} & \multicolumn{2}{|c|}{$\begin{array}{l}95 \% \text { Confidence } \\
\text { Interval of the } \\
\text { Difference }\end{array}$} \\
\hline & & & & & & & & & Lower & Upper \\
\hline \multirow[t]{2}{*}{$\begin{array}{l}\text { Post- } \\
\text { test }\end{array}$} & $\begin{array}{l}\text { Equal } \\
\text { variances } \\
\text { assumed }\end{array}$ & 3.437 & .069 & 5.021 & 58 & .000 & 1.60000 & .31864 & .96217 & 2.23783 \\
\hline & $\begin{array}{l}\text { Equal } \\
\text { variances } \\
\text { not assumed }\end{array}$ & & & 5.021 & 54.728 & .000 & 1.60000 & .31864 & .96136 & 2.23864 \\
\hline
\end{tabular}


Ethnomathematics-based- e-Module development was able to improve students' metacognitive ability. The teachers and students gave positive responses on the use of e-Module. The utilization of technology can enhance collaborative and exciting learning [2]. The use of digital books makes learning more interesting; it is also easy to use and can be carried everywhere because it is accessible through smartphones. e-Module can also be accessed via a smartphone or laptop that makes it more flexible. With the e-Module, students can access subject matter from anywhere and anytime, and students who do not have math textbooks can learn through e-modules [3], [4], [35].

Learning activities in this e-Module allow students to generate reasoning, find their answers and collect and observe information as new learning experiences. Activities in the scientific approach include: 1) observing, 2) experimenting, 3) reasoning, 4) asking questions, and 5) communicating. The ethnomathematics-based e-Module uses a scientific approach that consists of 4 stages of 1) observing, 2) asking, 3) reasoning, 4) trying. In the early stages, students are given examples, illustrations, cases, or problems of building space associated with Sasak culture. Students can ask the teacher about the practical issues or things that are not understood about the sub-material to be studied at the questioning stage. At the reasoning, stage students try to understand the concept/ material by working on the questions given. Students also process the information collected to make conclusions related to the concept/material being studied at this reasoning stage. Students begin to design strategies, develop strategies, and implement the chosen techniques to solve problems and use numeracy, algebraic, and geometric skills at the trying stage. At this stage, students also process the information that has been collected to make conclusions related to the concept/material being studied. The orientation of this scientific approach is to encourage students' curiosity about natural phenomena, and students are actively involved in constructing concepts and knowledge [8].

\subsection{Disseminating stage}

The socialization stage of the learning media is carried out in schools through the school website and the E-Modul link distributed via Whatsapp Group.

\section{Conclusion}

Education and training are the best investments in society's future [36]. They play a vital role in boosting growth, innovation, and job creation. The government's education and training systems need to give people the forward-looking knowledge, skills, and competencies they need to innovate and prosper. They also have an essential role in creating an identity, building on shared values and cultures. Children think mathematically long before they start school and mathematical thinking is a strong predictor for later academic success in school-indeed, it is a better predictor than early reading and early attention skills [37], [38]. Mathematics is fundamental to a child's development \& communication in later life. Basic numeracy skills assist kids in terms of achievement \& just being competent adults. A broader acknowledgment of this would lead to more parity with literacy. However, developing a solid foundation in early math skills is vital for 
later educational success and economic, health, and employment outcomes. Children who enter school with solid mathematics skills have a greater likelihood of success in mathematics in kindergarten and in later grades [39], [40].

The result of the present study is a valid, practical, and effective e-Module product. Based on the validity test, the ethnomathematics based on e-Module $\mathrm{n}$ is highly feasible to use in learning resources with an average score of 3.65 (valid). Students' questionnaire response shows that the e-Module was practical with a percentage of the practicality of $89 \%$. The effectiveness of the e-Module was seen from the paired sample T-test used to compare the results of the pretest and post-test with the outcome of 0.00 $(\mathrm{p}=<0.05)$, indicating that there was a significant difference. In sum, there was a substantial effect of the ethnomathematics-based- e-Module use on students' metacognitive skills in solving spatial problems.

\section{References}

[1] A. D. Puspitasari, "Application of Learning Media for Physics Using Print Modules and Electronic Modules for High School Students," J. Phys. Educ., vol. 7, no. 1, pp. 2550-0325, 2019.

[2] D. Handayani, E. Elvinawati, I. Isnaeni, and M. Alperi, "Development of Guided Discovery Based Electronic Module for Chemical Lessons in Redox Reaction Materials," Int. J. Interact. Mob. Technol., vol. 15, no. 7, pp. 94-106, 2021, doi: https://doi.org/10.3991/ijim. v15i07.21559

[3] A. S. Nur, S. B. Waluya, R. Rochmad, and W. Wardono, "Contextual Learning with Ethnomathematics in Enhancing the Problem Solving Based on Thinking Levels," Journal Res. Adv. Math. Educ., vol. 5, no. 3, pp. 331-344, 2020, doi: https://doi.org/10.23917/jramathedu. $\underline{\mathrm{v} 5 \mathrm{i} 3.11679}$

[4] S. Astriani, S. Utaminingsih, and S. Surachmi, "Development of Ethno-mathematics Based Mathematics Teaching Material Technology: A Needs Analysis," J. Phys. Conf. Ser., vol. 1823, no. 1, 2021, doi: https://doi.org/10.1088/1742-6596/1823/1/012071

[5] S. Supiyati, F. Hanum, and J. Jailani, "Ethnomathematics in Sasaknese Architecture," J. Math. Educ., vol. 10, no. 1, pp. 47-57, 2019, doi: https://doi.org/10.22342/jme.10.1.5383.47-58

[6] M. Rosa et al., Current and future perspectives of ethnomathematics as a program. 2011.

[7] S. F. D. Patri and S. Heswari, "Development of Ethnomathematic-Based on Mathematics e-Module to Improve Students' Logical Thinking Skills," AIP Conf. Proc., vol. 2330, no. March 2021, doi: https://doi.org/10.1063/5.0043250

[8] I. D. Hastuti, Surahmat, Sutarto, and Dafik, "The Effect of Guided Inquiry Learning in Improving Metacognitive Skill of Elementary School Students," Int. J. Instr., vol. 13, no. 4, pp. 315-330, 2020, doi: https://doi.org/10.29333/iji.2020.13420a

[9] D. Setiawan and I. Wilujeng, "The Development of Scientific-Approach-Based Learning Instruments Integrated with Red Onion Farming Potency in Brebes Indonesia," J. Pendidik. IPA Indones., vol. 5, no. 1, pp. 22-30, 2016, doi: https://doi.org/10.15294/jpii.v5i1.5785

[10] Sutarto et al., "The Effect of Problem-Based Learning on Metacognitive Ability in the Conjecturing Process of Junior High School Students," Educ. Res. Int., vol. 2022, 2022, doi: https://doi.org/10.1155/2022/2313448

[11] A. Zohar and S. Barzilai, "Metacognition and Teaching Higher Order Thinking (HOT) in Science Education: Students' Learning, Teachers' Knowledge and Instructional Practices," Routledge Int. Handb. Res. Teach. Think., no. June, pp. 229-242, 2015. 
[12] I. D. Hastuti, Surahmat, Sutarto, and Dafik, "Shifting of Perfective Metacognitive Activities in Solve Math Problems," J. Phys. Conf. Ser., vol. 1465, no. 1, 2020, doi: https://doi. org/10.1088/1742-6596/1465/1/012041

[13] L. Dörr and F. Perels, "Improving Metacognitive Abilities as an Important Prerequisite for Self-Regulated Learning in Preschool Children," Int. Electron. J. Elem. Educ., vol. 11, no. 5, pp. 449-459, 2019, doi: https://doi.org/10.26822/iejee.2019553341

[14] J. H. Flavell, P. H. Miller, and S. A. Miller, Cognitive development. New Jersey: Prentice Hall., 2002.

[15] L. W. Anderson et al., Taxonomy for_Assessing a Revision OF Bl00M'S TaxONOMy oF EducatiONal Objectives. 2001.

[16] V. Serevina, Sunaryo, Raihanati, I Made Astra, and I. J. Sari, "Development of e-Module Based on Problem Based Learning (PBL) on Heat and Temperature to Improve Student's Science Process Skill," TOJET Turkish Online J. Educ. Technol., vol. 17, no. 3, pp. 26-36, 2018.

[17] I. Kurniasari, R. Rakhmawati, and J. Fakhri, "Development of e-Module Establishing Ethnomathematics in Building Road Side Material," Indones. J. Sci. Math. Educ., vol. 01, no. November, pp. 227-235, 2018. https://doi.org/10.24042/ijsme.v1i3.3597

[18] S. Papadakis and M. Kalogiannakis, "Mobile Educational Applications for Children. What Educators and Parents Need to Know." Int. J. Mob. Learn. Organ., vol. 11, no. 2, p. 1, 2017, doi: https://doi.org/10.1504/IJMLO.2017.10003925

[19] S. Papadakis, N. Zaranis, and M. Kalogiannakis, "Parental Involvement and Attitudes Towards Young Greek Children's Mobile Usage," Int. J. Child-Computer Interact., vol. 22, p. 100144, 2019, doi: https://doi.org/10.1016/j.ijcci.2019.100144

[20] D. A. Lieberman, C. H. Bates, and J. So, "Young Children's Learning With Digital Media," Comput. Sch., vol. 26, no. 4, pp. 271-283, Nov. 2009, doi: https://doi. org/10.1080/07380560903360194

[21] M. Huda et al., "Empowering Children with Adaptive Technology Skills: Careful Engagement in the Digital Information Age," Int. Electron. J. Elem. Educ., vol. 9, no. 3, pp. 693-708, 2017.

[22] K. Larkin and N. Calder, "Mathematics Education and Mobile Technologies," Math. Educ. Res. J., vol. 28, no. 1, pp. 1-7, 2016, doi: https://doi.org/10.1007/s13394-015-0167-6

[23] A. Bray and B. Tangney, "Enhancing Student Engagement through the Affordances of Mobile Technology: A 21st Century Learning Perspective on Realistic Mathematics Education," Math. Educ. Res. J., vol. 28, no. 1, pp. 173-197, 2016, doi: https://doi.org/10.1007/ s13394-015-0158-7

[24] L. Chmiliar, "Improving Learning Outcomes: The iPad and Preschool Children with Disabilities," Front. Psychol., vol. 8, no. May, pp. 1-11, 2017, doi: https://doi.org/10.3389/ fpsyg.2017.00660

[25] J. P. Smith, J. Roschelle, and A. DiSessa, "Misconceptions Reconceived: A Constructivist Analysis of Knowledge in Transition," J. Learn. Sci., vol. 3, no. 2, pp. 115-163, 1993, doi: https://doi.org/10.1207/s15327809j1s0302_1

[26] E. L. Swing and C. A. Anderson, "How and What do Videogames Teach?," Children's Learning in a Digital World. pp. 64-84, Nov. 13, 2007, doi: https://doi.org/10.1002/ 9780470696682.ch3

[27] L. B. Thorell, S. Lindqvist, S. Bergman Nutley, G. Bohlin, and T. Klingberg, "Training and Transfer Effects of Executive Functions in Preschool Children," Dev. Sci., vol. 12, no. 1, pp. 106-113, Jan. 2009, doi: https://doi.org/10.1111/j.1467-7687.2008.00745.x

[28] J. E. Johnson and J. F. Christie, "Play and Digital Media," Comput. Sch., vol. 26, no. 4, pp. 284-289, Nov. 2009, doi: https://doi.org/10.1080/07380560903360202 
[29] S. Papadakis, M. Kalogiannakis, and N. Zaranis, "Teaching Mathematics with Mobile Devices and The Realistic Mathematical Education (RME) Approach in Kindergarten," Adv. Mob. Learn. Educ. Res., vol. 1, no. 1, pp. 5-18, 2021, doi: https://doi.org/10.25082/ AMLER.2021.01.002

[30] B. Rocha and C. Nunes, "Benefits and Damages of the Use of Touchscreen Devices for the Development and Behavior of Children under 5 Years Old-a Systematic Review," Psicol. Reflexão e Crítica, vol. 33, no. 1, p. 24, 2020, doi: https://doi.org/10.1186/ s41155-020-00163-8

[31] W. Widada, D. Herawaty, and A. N. M. T. Lubis, "Realistic Mathematics Learning Based on the Ethnomathematics in Bengkulu to Improve Students' Cognitive Level," J. Phys. Conf. Ser, vol. 1088, 2018, doi: https://doi.org/10.1088/1742-6596/1088/1/012028

[32] A. Kuzle, "Patterns of Metacognitive Behavior During Mathematics Problem-Solving in a Dynamic Geometry Environment," Int. Electron. J. Math. Educ., vol. 8, no. 1, pp. 20-40, 2013. https://doi.org/10.29333/iejme/272

[33] D. Herawaty, W. Widada, T. Novita, L. Waroka, and A. N. M. T. Lubis, "Students' Metacognition on Mathematical Problem Solving through Ethnomathematics in Rejang Lebong, Indonesia," J. Phys. Conf. Ser., vol. 1088, 2018, doi: https://doi. org/10.1088/1742-6596/1088/1/012089

[34] S. L. Wismath, D. Orr, and B. Good, (2014). Metacognition: Student Reflections on Problem Solving. Journal on excellence in college teaching.

[35] A. Fatahillah, I. D. Puspitasari, and S. Hussen, "The Development of Schoology Web-Based learning media with GeoGebra to Improve the ICT Literacy on Quadratic Functions," Journal Res. Adv. Math. Educ., vol. 5, no. 3, pp. 304-316, 2020, doi: https://doi.org/10.23917/ jramathedu.v5i3.10692

[36] T. Karakose and R. Yirci, "Exploring the Interrelationship between COVID-19 Phobia, Work-Family Conflict, Family-Work Conflict, and Life Satisfaction among School Administrators for Advancing Sustainable Management," 2021. https://doi.org/10.3390/ $\underline{\mathrm{su} 13158654}$

[37] S. Papadakis, M. Kalogiannakis, and N. Zaranis, "Comparing Tablets and PCs in teaching Mathematics: An attempt to improve Mathematics Competence in Early Childhood Education," Presch. Prim. Educ., vol. 4, no. 2, p. 241, 2016, doi: https://doi.org/10.12681/ ppej.8779

[38] S. Papadakis, M. Kalogiannakis, and N. Zaranis, "The Effectiveness of Computer and Tablet Assisted Intervention in Early Childhood Students' Understanding of Numbers. An empirical Study Conducted in Greece," Educ. Inf. Technol., vol. 23, no. 5, pp. 1849-1871, 2018, doi: https://doi.org/10.1007/s10639-018-9693-7

[39] S. Papadakis, M. Kalogiannakis, and N. Zaranis, "Improving Mathematics Teaching in Kindergarten with Realistic Mathematical Education," Early Child. Educ. J., vol. 45, May 2017, https://doi.org/10.1007/s10643-015-0768-4

[40] N. Zaranis, M. Kalogiannakis, and S. Papadakis, "Using Mobile Devices for Teaching Realistic Mathematics in Kindergarten Education," Creat. Educ., vol. 04, no. 07, pp. 1-10, 2013, https://doi.org/10.4236/ce.2013.47A1001

\section{$7 \quad$ Authors}

Sutarto is a lecture at the Faculty of Sciences Technology and Applications, Universitas Pendidikan Mandalika, Indonesia. Email: sutarto@undikma.ac.id 
Ahmad Muzaki is a lecture at the Faculty of Sciences Technology and Applications, Universitas Pendidikan Mandalika, Indonesia. Email: ahmadmuzaki@undikma.ac.id

Intan Dwi Hastuti is a lecture at Elementary School Teacher Education, Faculty of Teacher Training and Education, Universitas Muhammadiyah Mataram, Indonesia. Email: intandwihastuti88@gmail.com.

Sukron Fujiaturrahman is a lecture at Elementary School Teacher Education, Faculty of Teacher Training and Education, Universitas Muhammadiyah Mataram, Indonesia. Email: sukronfu27@,gmail.com.

Zainuddin Untu is a lecture at the Faculty of Teacher Training and Education, Universitas Mulawarman, Indonesia. Email: zainuddin.untu70@gmail.com

Article submitted 2021-06-20. Resubmitted 2021-08-16. Final acceptance 2021-12-14. Final version published as submitted by the authors. 